\title{
Federal Class Size Reduction Policy: A Case Study Testing John W. Kingdon's THEORY ON AGEnda SETTING
}

\section{By Sue Rohan Associate Editor: Jeff Marootian}

Abstract: According to policy theorist John W. Kingdon's theory on agenda setting, three streams of problems, politics, and policy alternatives converge to create a window of opportunity that allows an issue to move onto the policy-setting agenda. In 1999 the policysetting agenda included former President Bill Clinton's class size reduction policy despite many decades of conflict over the policy and inaction at the federal level. It appears that a change in the political stream created a window of opportunity that allowed class size reduction to arrive on the agenda. By examining enrollment data, average class size and teacher-pupil ratio trends, national perceptions, developments in policy approaches, and political factors, this study concludes that class size reduction is an example of Kingdon's theory.

\section{INTRODUCTION}

In his book, Agenda, Alternatives, and Public Policies, John W. Kingdon (1995) asserts that [governmental] "agendas are set by problems or politics, and alternatives are generated in the policy stream" (p. 20). When the three streams of problems, politics, and policy come together at the same time, a window of opportunity occurs, issues come onto the agenda, and the result is significant movement, or non-incremental change, on a federal issue. This article explores whether former President Clinton's class size reduction policy, a key initiative for reforming elementary and secondary education in the U.S., was an example of Kingdon's threestream theory. Was this policy placed on the federal agenda in May 1998 because three independent streams identification of problems, generation of policy alternatives, and politics - came together during a window of opportunity to arrive at non-incremental change?

In the case of class size, two of the streams, problem identification and policy alternatives, flowed for many years, with considerable debate and lack of consensus. However, it appears that it was not until the stream of politics became a factor in 1998 that the class size reduction issue was put onto the former President's agenda. As the three streams came together, the issue of class size was addressed and resulted in a policy change for 1999.

The class size reduction (CSR) policy, a provision included in the Omnibus Spending Bill of the $105^{\text {th }}$ Congress, was intended to substantially improve teaching, and thus student achievement, in first through third grade. The CSR program allocated $\$ 1.2$ billion in federal funds for schools to recruit, hire, and train 30,000 new teachers in the 1999/2000 academic year to reduce class size from a national average of 22 to 18 students per class. After submitting an application, each state received funds using a formula based on several factors including the state's share of Title I funds, percent of poverty level, and percent of school enrollment.

This study examines Kingdon's three streams as they relate to class size. The extent to which a problem with class size existed is explored through data on enrollment, average class size, teacher-pupil ratio, and national perceptions. A review of the journal articles examines developments in policy approaches. Finally, the stream of politics is addressed by looking at national mood regarding class size reduction and educational reforms through the lens of newspaper articles.

John Kingdon's theory provides a perspective on why some issues and alternative solutions come to the federal agenda. He theorizes that the flow of the three streams of problems, politics, and policy are three independent processes that occur with three different groups that hold different values. Although any group can have an effect on any part of the process, Kingdon finds that participants specialize to some degree. This specialization usually includes people in and around government who identify problems through systematic indicators, by focusing events like crises and disasters, or by feedback from the operation of current programs; a

Sue Rohan holds a Master of Philosophy degree and is a candidate for a Doctor of Philosophy degree in Public Policy, both from The George Washington University. She is studying federalism as it applies to education policy. Ms. Rohan is Director of Intergovernmental Affairs for the Centers for Medicare and Medicaid Services, She received both a Bachelor of Science degree in Education and a Master of Science degree in Educational Administration from the University of Wisconsin-Madison. 
visible cluster made up of the president and prominent members of Congress involved in the politics; and an invisible cluster of specialists in the bureaucracy and in professional communities shaping the policy alternatives.

Kingdon suggests that at any point in time each of the groups and each of the three processes may constrain or promote inclusion of an item on the agenda. In the case of class size reduction, for many decades the public, especially parents and teachers, viewed class size as a problem, particularly for students in kindergarten through third grade. Despite the interest in class size as a problem, it did not appear that the nation reached consensus on if or why class size was a problem. This study examines enrollment data from 1950 to 1995 , average class size data for 1987 to 1997 , and class ratio data for 1949-50 to 199394 to determine if dramatic changes in class size propelled the issue onto the agenda. It also explores the national perceptions about class size and the benefits of small classes to determine if perception changed substantially and pushed the issue onto the agenda. In addition, the study looks at opinion surveys and articles on class size taken from a Lexis-Nexis search of articles from 1975 to 1998 to detect any change in public perception of the issue.

Academic researchers, state officials, and educators experimented with class size reduction policy options for several decades. The second line of exploration to assess the applicability of Kingdon's theory is to determine if a new policy approach emerged just prior to 1998 that raised the concept of class size reduction to the agenda. The study examines major research on the effectiveness of class size reduction through a review of journal articles from 1970 to 1998.

Clinton was the key political promoter of class size reduction at the national level. As a prominent figure, he was a visible supporter of policy change, and his support appeared to be politically motivated. The study examines the roll of politics as a factor in moving class size reduction to the agenda. A review of newspaper articles from 1969 to 1998 evaluates whether a swing in the national mood occurred that made class size reduction a more appealing proposal.

Furthermore, the stream of politics is compared to the other streams to determine if it was more important than identification of a compelling problem or policy in gaining action on this issue. If problems were more important, one would expect that overcrowding peaked or rapidly increased in the 1990s or that public perceptions of the problem changed dramatically. If politics were more important, one would expect to see evidence of swings in the national mood, administration or legislative turnover, or interest group pressure campaigns. Furthermore, if contrary to Kingdon's assertions, generation of policy alternatives was more important than the other two forces, then one would expect that just prior to adoption of the policy, research on the impact of reducing class size generated dramatic new confirmations on its importance in improving student achievement in a cost effective manner.

\section{ANALYSIS \\ Problem Identification}

Did significant changes in school enrollment create a crisis or disaster and become a determining factor in the class size reduction policy being placed on the agenda? The study looks at National Center for Education Statistics (1997) enrollment data in regular public elementary and secondary schools for the years from 1950 through 1998. The data for 1996 - 1998 are projected enrollments since final figures were not available at the time the policy decision was under consideration. Figure 1, "Enrollment in Public K-12 Schools," which depicts the enrollment level over this period, shows that enrollment grew steadily from 1950 to 1971, declined from 1971 to 1985 , and then rose steadily again from 1985 to 1998 .

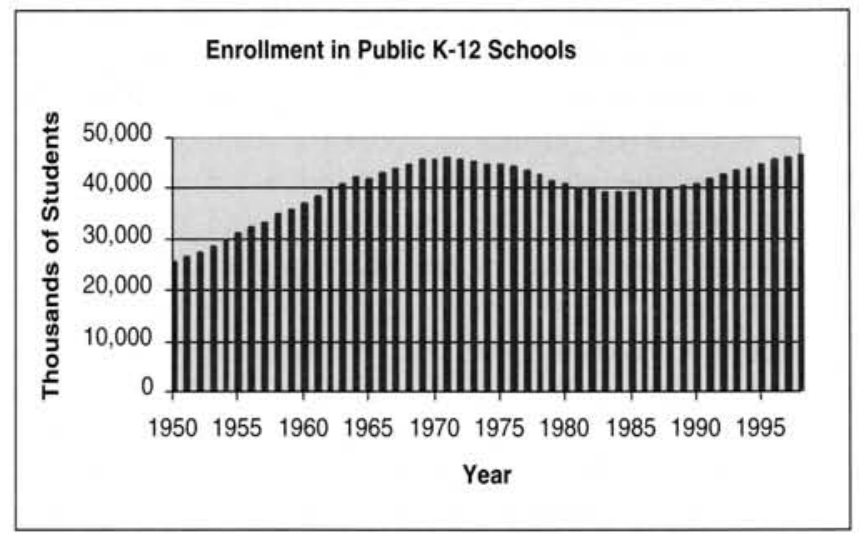

\section{Figure 1: Enrollment in Public Elementary and Secondary Schools}

Overall, it does not appear that any dramatic or unexpected change in the number of students enrolled in public schools occurred in the years leading up to 1998 . Growth was steady and predictable; therefore it is unlikely that the gradual growth in the number of students created a crisis that influenced passage of the class size reduction policy.

In addition to the number of students, the study looked at National Center for Education Statistics (1997) data on the average elementary class size over the years. Figure 2, "Average Class Size," shows that the average class size had not grown in the years prior to 1998 . Instead, it declined somewhat in the elementary grades from 24.5 students per class in 1987 to 24.1 students in 1993. In secondary classes the level remained relatively constant at 23.9 students in 1987 and 23.6 in 1993. 


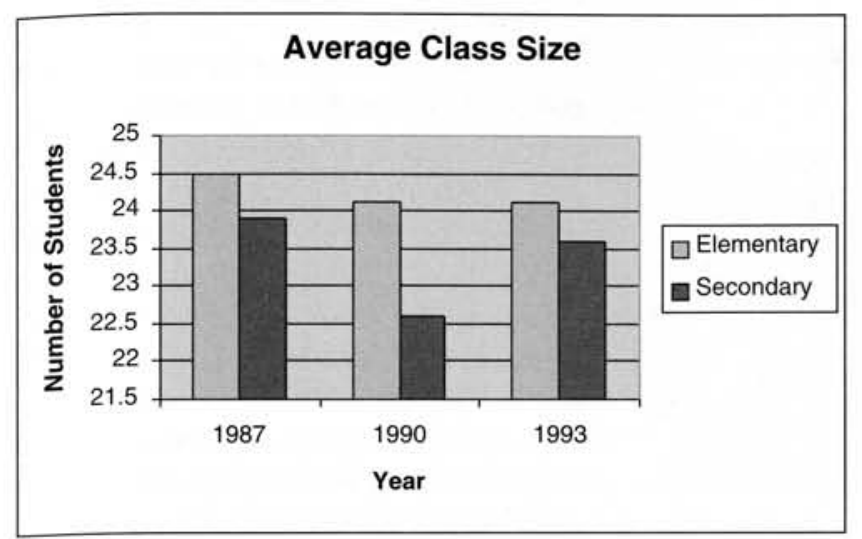

Figure 2: Average Class Size in U.S. Elementary and Secondary Schools

Average class size was somewhat smaller for secondary classes than for elementary classes. Figure 3 shows that overall total average class size across elementary and secondary classes combined declined slightly from 23 in 1991 to 22 in 1997. In summary, the data do not depict an increase in class size despite the increasing enrollments in the last decade. The slight decrease in class size that occurred is contrary to what one would have expected if changes in class size created a crisis or disaster that moved class size reduction onto the agenda.

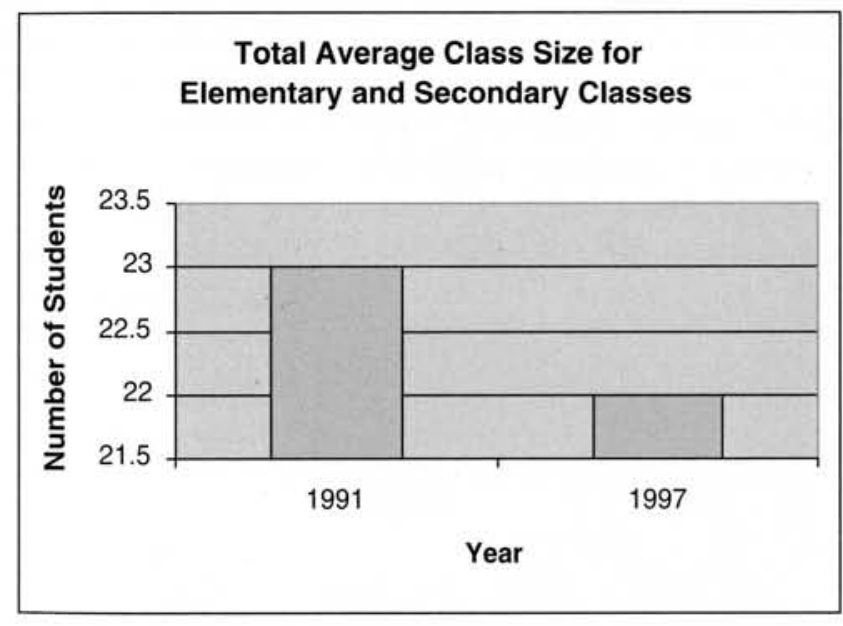

Figure 3: Total Average Class Size for Elementary and Secondary Classes Combined

Another measure of change in class size over the years is the pupil-teacher ratio. Pupil-teacher ratio refers to the number of students divided by the number of staff classified as teachers. This ratio is smaller than class size average because full- and part-time teachers are counted along with specialists, coordinators, and administrators, regardless of the load they carry (McCants, 1995, p. 16).

Class size refers to the actual number of students in a classroom with a teacher (American Federation of
Teachers, 1998, p. 3). However, the trend in the ratio provides an indication of change over time. Figure 4, "Pupil-Teacher Ratio," shows that this ratio declined steadily since 1955, just as class size declined (National Center for Education Statistics, 1993).

It is also evident that elementary classes were larger than secondary classes, but the pupil-teacher ratio in elementary classes declined steadily from 20.9 in 1955 to 14.6 in 1992. Data for years after 1992 were not yet available, however given the decline in class size (cited in Figure 3) from 1991 to 1997 , one would expect to see a corresponding decline in pupil-teacher ratio. The declining trend in pupil-teacher ratio is contrary to what

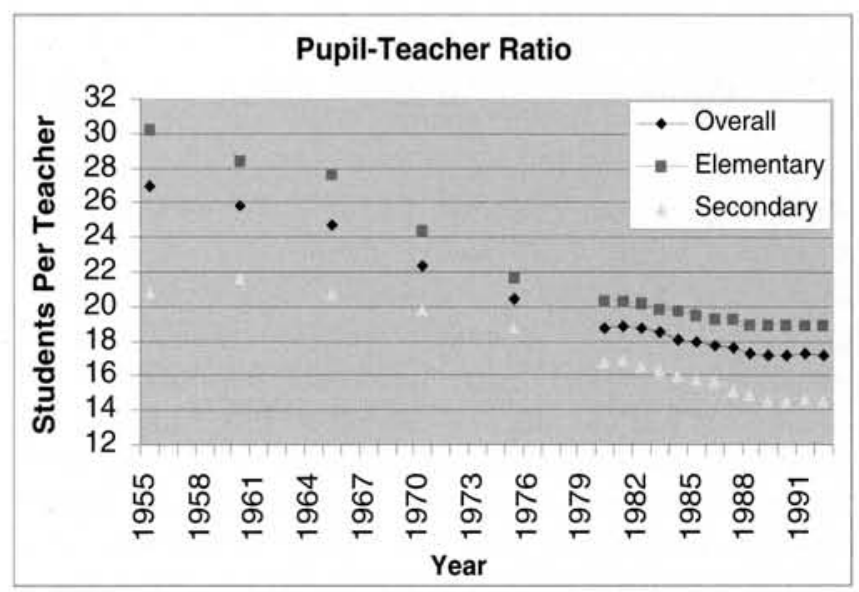

Figure 4: Pupil-Teacher Ratio

one would expect if the conditions surrounding class size were indicative of a crisis.

The study explored whether national perceptions on class size changed just prior to 1998 and whether class size was viewed as a disaster or crisis. The annual Gallup Poll published in Phi Delta Kappan on American views about education for the years 1976 - 1998 provided evidence of national perceptions. The poll is based on inhome interviews of over 1500 adults from across the nation in all types of communities (Xinahua News Agency, 1989, p. 1). No mention was made of class size as an issue until the $21^{\text {st }}$ poll in 1989 when 75 percent of interviewees indicated they favored reducing class size in the early grades to as few as 15 pupils. In addition, 68 percent of interviewees were willing to pay higher taxes for the extra expense. This perception was present a decade prior to placement of the class size policy on the national agenda.

In a 1990 excerpt from a Simon \& Schuster Consumer Group Book, The School Match Guide to Public Schools, Bainbridge and Sundre (1990, p.1) indicated that based on a survey, 61.1 percent of parents prefer "small" or "very small" class sizes for elementary school students. They also indicated that 56 percent of 


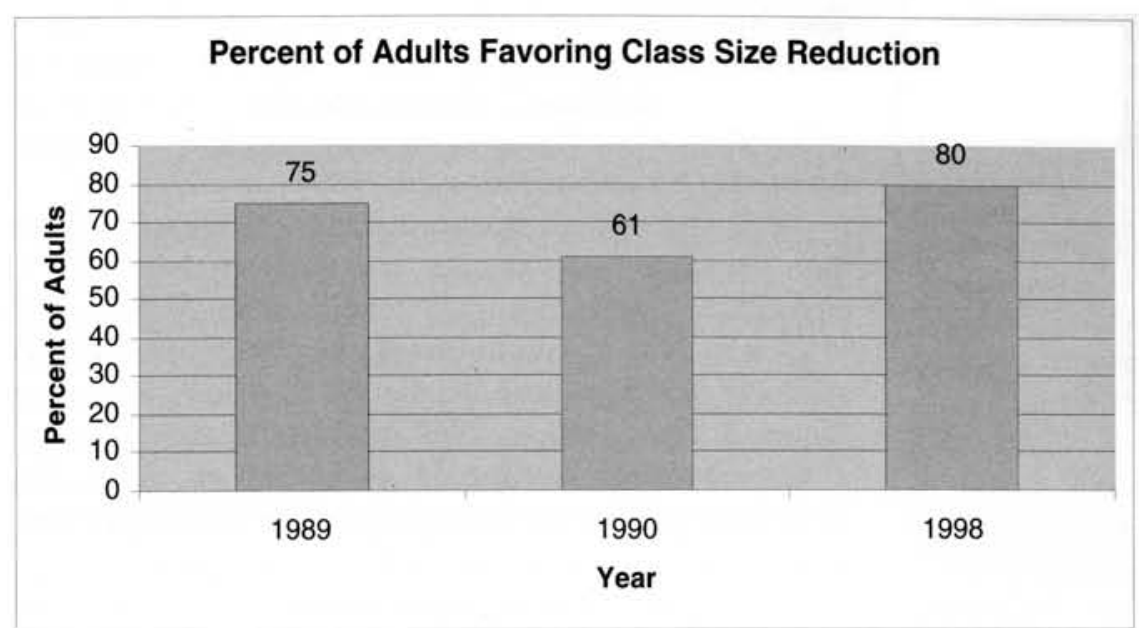

Figure 5: Percent of Adults Favoring Class Size Reduction

perceptions may be a factor in the window of opportunity for change, but it does not seem to be the propelling factor to get class size reduction on the agenda.

Another indicator of changing perceptions in the class size issue is revealed in a search of all magazine articles in the Lexis-Nexis database that mention class size since 1975. Figure 6 shows an increase in articles from between zero and three in the 1975 to 1992 time frame to 36 in 1998, with fairly steady growth in the 1990s.

The steady growth in this sample of articles after 1989 adds to the view that public perception changed steadily to open the window of

parents felt average class sizes were suitable for junior and senior high school students. In 1998, the $30^{\text {th }}$ Phi Delta Kappan Gallup Poll asked a question about the Democratic proposal in Congress to reduce class size in grades 1-3. Eighty percent of respondents favored the proposal, somewhat higher than the responses to the above class size questions in 1989 and 1990. Although the questions and the polling techniques were not the same, the trends in these three polls provide an indication of whether there was a dramatic change or a feeling of a crisis in national perception. As shown in Figure 5, the percentage of adults responding to the three surveys who favored class size reduction did not change dramatically in the ten years from 1989 to 1998.

No data were found regarding public perceptions about class size or the need for reduction prior to 1989. However, Baumgartner and Jones (1993) report much more dramatic shifts in media attention or number of hearings prior to legislative action on a number of issues when compared with changes in perception on class size. Thus, changes in

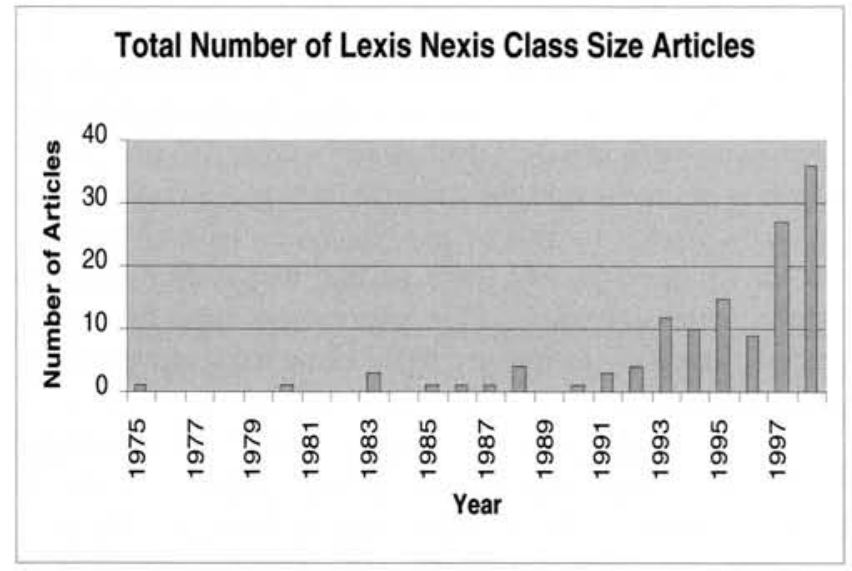

Figure 6: Number of Lexix-Nexis Magazine Articles Discussing Class Size By Year opportunity. However, the number of articles just prior to class size reaching the agenda does not appear to indicate a perception of crisis proportions since the total in 1998 is only 36 articles in a wide array of magazines, including education journals such as Phi Delta Kappan and popular magazines such as Newsweek, U.S. News \& World Report, Business Week, The Nation, and National Tax Journal.

In addition to the number of articles, the study examined whether the articles reported that reducing class size was effective. Articles were sorted into possible perceptions about class size reduction as "effective," "not effective," "mixed results," and "cannot determine." Articles in the "cannot determine" category were often those reporting on someone else's work without taking a stand as to effectiveness. Of the 179 articles reviewed 39 were coded as "effective," 7 as "mixed," 12 as "not effective," and 85 as "cannot determine." Thirty-one of the articles were found to be irrelevant to the topic. Four

\section{Perceived Effectiveness of Class Size Reduction}

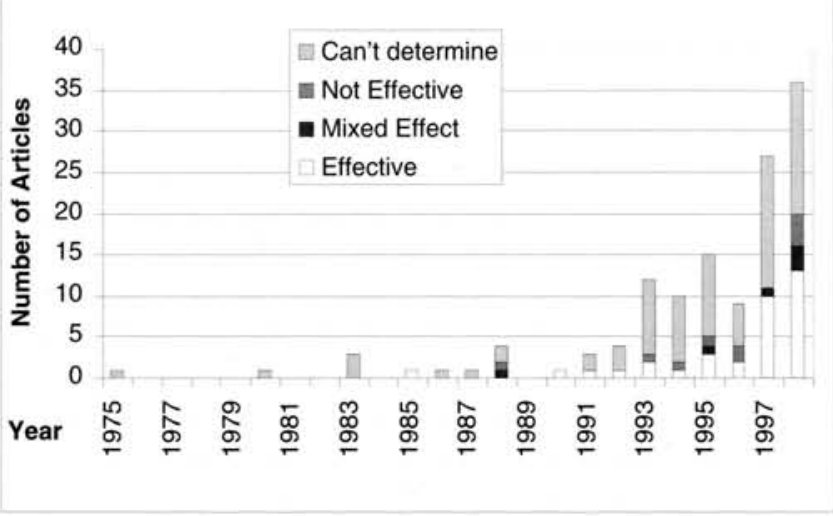

Figure 7: Perceived Effectiveness of Class Size Reduction by Year 
articles were exact duplicates in the database and were not double counted in the tallies given here. Of those where the view on effectiveness could be determined, $67 \%$ were favorable, $12 \%$ were mixed, and $21 \%$ were negative.

Figure 7 shows the distribution of articles and effectiveness perceptions by year. Although it is clear that the research and views on effectiveness were indeed mixed, the preponderance of the articles asserted that reducing class size would have a positive effect. It is also noteworthy that during the steady growth in the total number of articles after 1989, the number in which the articles indicated effectiveness of reduced class size also grew. Many of these articles were based on the research coming out of state reform efforts such as Indiana, California, Tennessee, and Wisconsin. In particular the Tennessee study, the STAR Project, commonly thought to be the largest and best-designed study, generated a large number of articles after 1991.

While class size was increasingly perceived as an issue to address during the $1990 \mathrm{~s}$, it did not appear that a crisis occurred just prior to class size reduction appearing on the national legislative agenda. Further investigation provides a perspective on why class size reduction was of interest and whether this policy might address a brewing crisis. The study looked at the 39 articles in all magazines in the Lexis-Nexis database from 1975 - 1998 in which CSR was deemed effective. Reasons for CSR were noted and when more than one reason was given, all reasons were captured independently, yielding a total of 50 reasons. Figure 8, "Reasons for Reducing Class Size," depicts the results of this analysis.

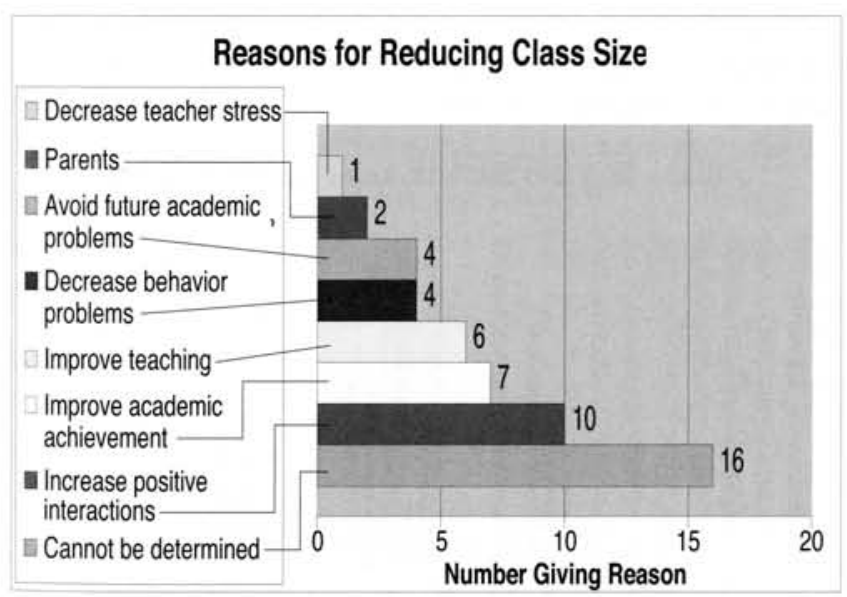

Figure 8: Reasons Given for Reducing Class Size

In most cases (16 out of 39 articles), although the article was favorable toward reducing class size, no reason was given for doing so. Of those giving a reason, most (10 out of 34 giving reasons) cited the opportunity to increase positive interactions with students. Positive interactions include getting to know the students better, providing extra attention, helping students to overcome feeling anonymous or uninvolved, developing a rapport with students, helping shy kids and giving them special attention, engaging the psychologically absent child, and increasing student participation. Although class size reduction is viewed favorably, the most commonly given reason for reducing class size - to increase positive interactions - does not convey a feeling of crisis or impending disaster.

Seven of the 39 articles cited improving student achievement or performance. Six cited opportunities to improve teaching such as the ability to cover more material, making knowledge relevant through individualized instruction, and spending more time on teaching. The next most frequently cited reasons tied at four each for decreasing behavioral or discipline problems and avoiding future academic problems such as special education placement, retention, and dropping out. The parents' category, cited twice, included more parental participation and parents preferring smaller classes for their children. Cited only once in this review was decreasing teacher stress. There does not seem to be a strong consensus on why class size is a problem, and hence it is difficult to interpret support for reducing class size as fixing some impending crisis or averting a huge disaster.

To determine if a crisis was pending, student achievement in the early grades was reviewed using the National Center for Education Statistic's available reading $(1992,1994,1998)$ and mathematics (1990, 1992, 1996) assessment results on the National Assessment of Educational Progress (NAEP) during the 1990s. Figure 9, "NAEP Reading Assessment," shows that with a scale score range of 0 to 500 , average fourth grade reading scale scores for public schools remained relatively constant between 1992 and 1998, varying by only three points.

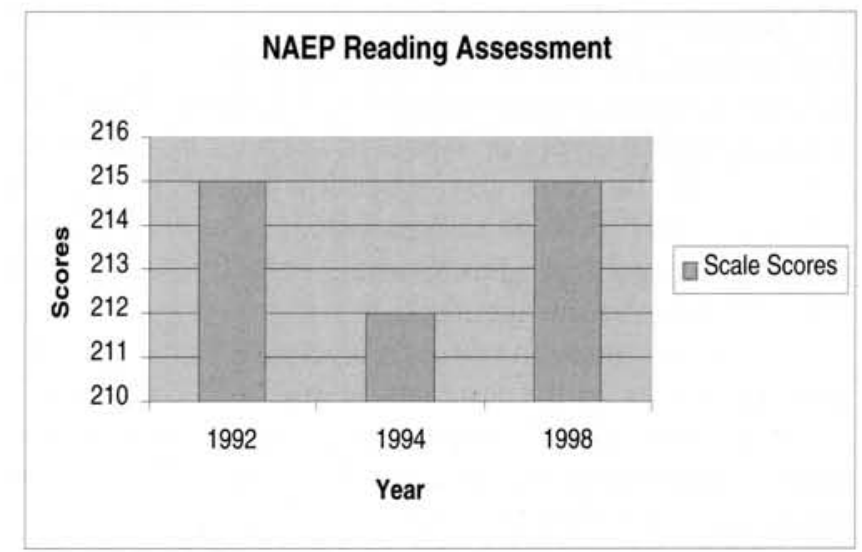

Figure 9: National Assessment of Educational Progress in Reading 
Figure 10 shows that with a scale score range of 0 to 500, NAEP mathematics scale scores improved significantly from 212 to 222 between 1990 and 1996, the opposite of what one would expect to see if a crisis were brewing prior to the class size policy reaching the agenda. Therefore, the review of student achievement in reading and mathematics does not confirm that a problem suddenly developed that propelled the class size policy to the agenda.

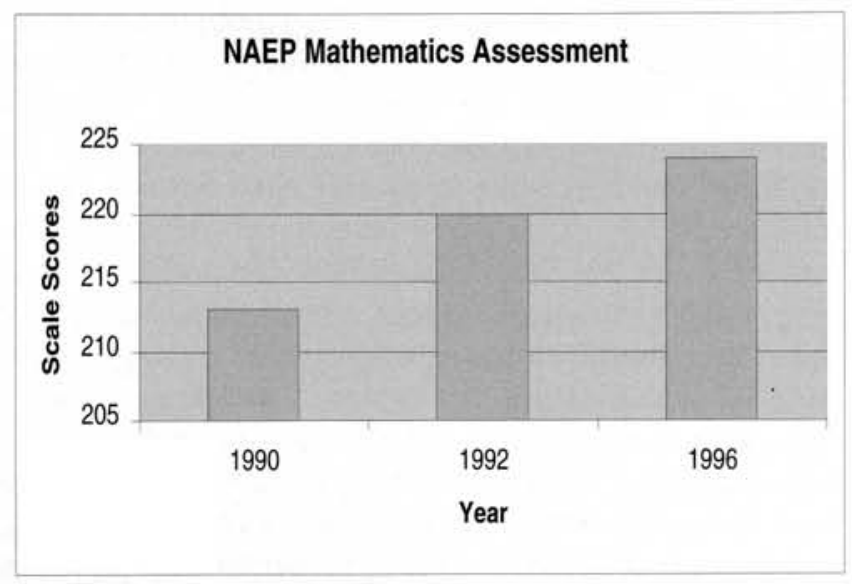

Figure 10: National Assessment of Educational Progress in Mathematics

Overall, when evaluating the stream of problem identification as it contributes to agenda setting, the evidence does not show that new problems were identified; that systemic indicators changed in unexpected or alarming ways; that events, crises, or disasters occurred; or that feedback from the operation of existing programs propelled the class size issue to the agenda.

\section{Policy Alternatives}

Kingdon's theory suggests problem identification and politics put an issue on the agenda, and policy alternatives are a secondary factor in agenda setting. This study tests this aspect of Kingdon's theory by reviewing the research on class size reduction to see if there is evidence that policy alternatives existed and were waiting for problem identification or politics to propel the CSR issue to the agenda.

Extensive research and state level policy changes took place primarily in the last half of the $20^{\text {th }}$ century and more recently in the 1990s leading to the formulation of policy approaches to reduce class size and improve education. However, in addition to being unclear about what reduced class size will accomplish, the research is mixed in whether class size reduction is effective in improving education. Some of the reasons cited above for reducing class size reflect classroom process improvements, such as "improve teaching" and "increase positive interactions" that will lead to improved educational outcomes. Other reasons refer primarily to outcome measures, such as "improved student achievement," "decreased behavior problems," and a "reduction in future academic problems." The study looked at the most commonly cited educational outcome measure, "improved student achievement," to determine if policy approaches have been found to be effective and if the research findings have been so compelling in the years just prior to 1998 that they propelled the issue of class size reduction to the agenda.

The study reviewed article abstracts from an Educational Resources Information Center (ERIC) search of class size studies from 1970 to 1998 . Studies of higher education class size or those that did not evaluate effects on student learning and achievement were not included. Reports were coded based on whether class size was considered an effective approach to improving student achievement as follows: "Effective," "Mixed" (includes those studies that refer to inconclusive data and findings, studies that find class size reduction to produce only slight gains, or studies that criticize class size reduction as more costly than other alternatives for improving achievement), and "Not Effective." Figure 11, "Class Size and Student Achievement Research," a summary of the number of reports and their coding over time, shows that the total number of studies fluctuated with peaks in 1980 and 1994 . The 1980 peak was largely a reaction to the Glass (1979) meta-analysis published the year before, which sparked considerable debate. In 1986, Bain and Achilles first reported the Tennessee STAR Project results. From 1986 on, a series of articles on the STAR Project and similar

Class Size and Student Achievement Research

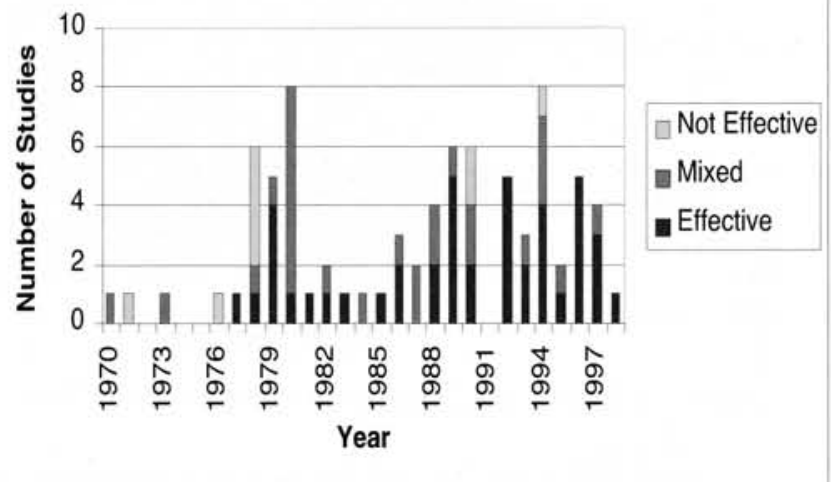

Figure 11: Class Size and Student Achievement Research

initiatives appeared. In 1994, the second peak, several states reported on small class size initiatives including Tennessee's STAR Project, Indiana's PRIME TIME 
initiative, and Wisconsin's Urban Initiative. Fairly steady growth in the research reports from 1986 to 1994 is seen with a decline in reports after 1994. If a breakthrough occurred in policy alternatives, it appears that the breakthroughs were in the 1978 to 1980 and 1986 to 1994 timeframes. In the years immediately prior to class size arriving on the agenda continuing research to support the 1986 reports appeared, but no dramatic new confirmations on its importance in improving student achievement were evident.

There was a change in the focus on and conclusions about class size and student achievement over time. In general, fewer studies found small class sizes ineffective, fewer studies found mixed results, and more studies found class size reduction effective in improving student achievement. Since the high of four in 1978, only three studies in the twenty years from 1979 to 1998 found small classes ineffective. In 1980 seven reports found small classes to have mixed results. That number dropped off significantly in later years with 0 to 3 studies per year yielding mixed results since 1981. At the same time that negative and mixed reports dropped off, reports finding small class size to be effective increased from none in $1970-1976$, to years like 1987, 1992, and 1996 where five reports indicated effectiveness. Figure 12 shows the proportion of studies coded effective, mixed, or not effective over the years.

As the number of reports finding small class size effective rose, several aspects of the research changed. In the 1970s and early 1980s most studies were conducted with class size of over 20 students per teacher. These studies often found little effect on student achievement. After about 1985 the classrooms studied usually consisted of fewer than 20 students per teacher. These later studies found the classes of fewer than 20 students to result in improved achievement.

In addition to changes in the size of classes studied, beginning in 1985, state and local government sponsored studies occurred and more studies used randomized assignment of students to experimental and control groups. For example, studies were conducted or reported in Indiana in 1985, Metro-Nashville in 1986, Mesa, Arizona in 1988, Tennessee in 1989, Burke County, NC in 1990, Chicago in 1990, Wisconsin in 1994, Nevada in 1995, Rockingham County, NC in 1996, Milwaukee in 1997, and New York City in 1997. Other states sponsored reviews of literature during this time (Alaska, Pennsylvania, and South Carolina). It appeared that state interest increased steadily and along with it, the resources to test effectiveness in a more controlled experimental setting.

In addition to better experimental methods being used, several of the class size studies involved research on lasting benefits. Most noteworthy were the Indiana PRIME TIME and Tennessee Project STAR studies. The Project STAR lasting benefits studies added credibility to the findings with Education Secretary Richard Riley $(1998$, p. 6) referring to this work as a "landmark, fouryear experimental study" and Harvard's Frederick Mosteller (1998, p.1) calling it "one of the great experiments in education." Donald Orlich of Washington State University referred to Project STAR in Phi Delta Kappan (April 1991) as "one of the most significant studies in education during the past 25 years." Robert Slavin (1999, p.1) of Johns Hopkins University called the STAR research a "watershed event." Jeremy Finn (1999, p.1) of State University of New York

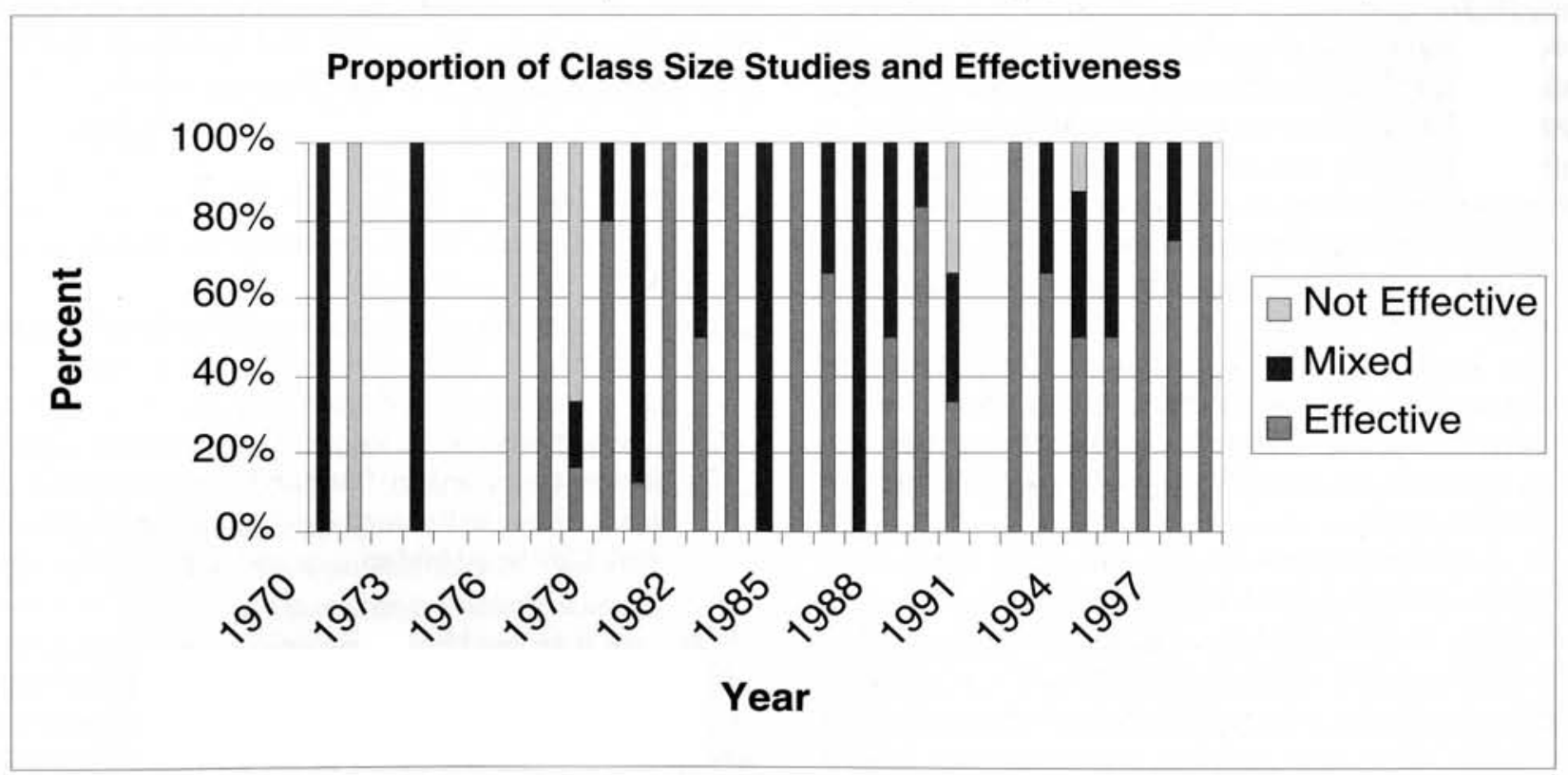

Figure 12: Proportion of Class Size Studies Coded by Effectiveness 
reported that the STAR research left no doubt that small classes have an advantage over larger classes in reading and math in the early primary grades.

If, contrary to Kingdon's theory, policy approaches were the key to class size reduction legislation moving onto the national decision making agenda, then one would expect that just prior to adoption of the policy, research on the impact of reducing class size generated dramatic new confirmations on its importance in improving student achievement in a cost-effective manner. Instead, the research showed a gradual and steady movement toward the view that small class size is effective and a refinement in understanding of what size classes must be to result in improved student achievement. The greatest changes in research conclusions came in 1986 and beyond, more than a decade prior to adoption of the class size policy. However, as noted by Gerald Bracey in Phi Delta Kappan, (September 1995) when referring to the STAR research, "Although the research was conducted over a five-year period from 1985 to 1990 and although the research has been reported in professional journals, it remains largely ignored by policy makers and reformers - at least at the national level" (p.2). Therefore, it does not seem that policy alternatives propelled the class size initiative to the agenda, but rather the approaches were refined prior to adoption and were ready when the window of opportunity opened. This conclusion supports Kingdon's three-stream agenda-setting theory as well.

\section{Politics}

The third stream to explore in the agenda-setting theory is the role that politics played in the class size reduction policy. This study hypothesizes that in the case of class size reduction, the stream of politics was more important than identification of a compelling problem in gaining action on an issue. If politics were more important one would expect to see swings in the national mood, administration or legislative turnover, or interest group pressure campaigns. The study explores the national mood by reviewing newspaper articles and press releases leading up to adoption of the legislation. Administration and legislative turnover were limited during the ongoing Clinton administration, thus this factor and interest group pressure campaigns are not explored in depth.

A Lexis-Nexis search of all New York Times newspaper articles or articles referring to the New York Times from 1969 to 1999 that included the words "class size" produced 826 articles. Using a table of random numbers, a starting number (7) was selected and every fifth article after that number was reviewed. Articles appearing after the adoption of the legislation were excluded. Articles were coded from the first page of the article or from an abstract, whichever was longer, based on perceptions of class size as "Favorable," "Mixed," "Unfavorable," or "Could Not Determine." Favorable articles included those that reported on efforts to reduce class size as well as those in which the writer took a favorable position toward small classes. Mixed articles included those in which the author acknowledged that small classes resulted in improvements, but other alternatives would be more cost effective. Unfavorable

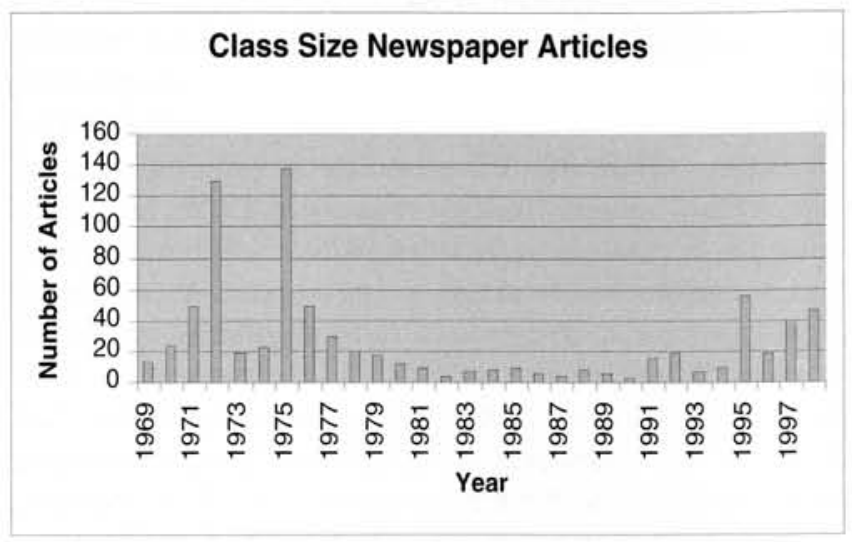

Figure 13: Distribution of Class Size
Newspaper Articles from 1969-1998

articles were those suggesting that smaller class sizes were not effective in improving achievement. Figure 13, "Class Size Newspaper Articles," shows the distribution by year of publication of all of the 826 articles over the years from 1969 to October 1998.

Figure 13 depicts a somewhat bimodal distribution with a high frequency of articles in the 1970s and another smaller surge in the late 1990s. The articles in the 1970s and 1990s were related to the following events.

\section{0s}

1971: The peak of student population caused overcrowding in the schools before the population began its decline in 1972 .

1972: Black and Hispanic students were bussed to white schools in New York City as a result of a controversial court decision.

1975: Teachers went on strike and a key issue was class size.

1976: Strikes continued in Pittsburgh and Louisville, KY, again related to the need for class size reduction. New York City faced budget cuts and growing class size.

\section{$1990 s$}

1991: Interest in class size begins to rise again, but the focus has changed. The focus is on smaller classes to improve student achievement and as an alternative to school choice. 
1995: Several states set limits on class size. The New York Times focused attention on the condition of schools and class size in New York City in an in-depth series.

1997: Articles focus on small class size to improve student achievement and threats to budgets that would undermine small class sizes.

1998: Articles address small class size in comparison to vouchers to improve schools.

During the 1970s, class size received considerable attention, but the interest was on overcrowding and excessive teacher workload much more so than on the effectiveness of teaching students in small classes. This difference in focus and attention is consistent with Baumgartner and Jones' (1993) theory of a Downsian mobilization. It appears that attention was generated to reduce class size due to overcrowding and workload, funds were provided to reduce class size somewhat, and attention to the issue declined significantly. Another mobilization is apparent during the late $1990 \mathrm{~s}$ when the focus changed to the relationship between student achievement and class size coupled with threats to public education through vouchers, charter schools, and school choice.

Figure 14 shows the tone of the sample of articles selected from the 826 articles that appeared in the search. Of those articles in which the tone could be determined, the vast majority were favorable toward reducing class

\section{Tone of Newspaper Articles}

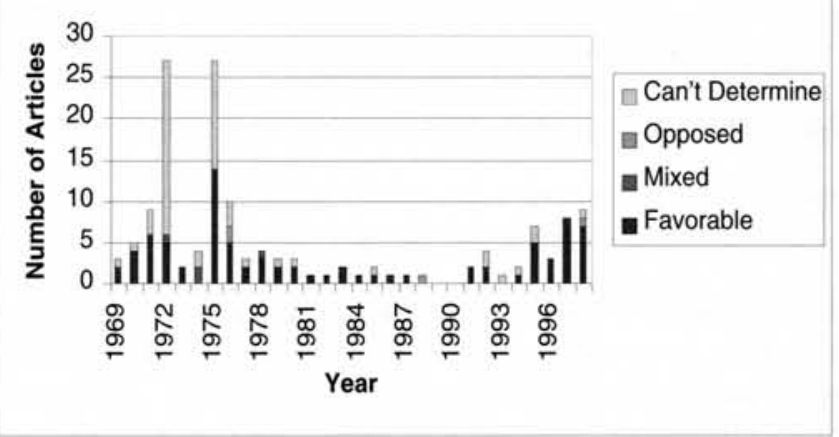

Figure 14: Tone of Sample of Class Size Newspaper Articles

size throughout all years studied. Very few articles were opposed and if they were, it was based on cost effectiveness rather than a lack of effectiveness in improving student achievement.

It appears that the national mood changed to the extent that interest in class size reduction was no longer an issue of overcrowding and workload as it was in the 1970s. The topic was not apparent as a concern in the 1980s. In the 1990s it became more prominent again, but with a change in focus. The focus seemed to build on the policy alternatives that showed smaller class size to be an effective method for improving student achievement. In addition, and perhaps more importantly, smaller class sizes became a political tool to combat the potential demise of public school education through vouchers, school choice, and charter schools.

In 1998, a Peter D. Hart \& Associates poll found that " $58 \%$ of Americans would be less likely to vote for a candidate who favors vouchers over smaller class size" (National Education Association, 1999, p.2). The National Education Association, a strong advocacy group, used this poll to reinforce the concept of a national consensus favoring their position to reduce class size. Congressional press releases issued May 14, 1998 just after President Clinton and Education Secretary Richard Riley introduced the class size reduction proposal reflected this national preference as well. A May 1998 press release from Congresswoman Barbara Lee (D-CA) was typical of the rhetoric surrounding the debate. She said, “... the Republican Congress continues to pursue an agenda which would undermine public education. Radical education experiments like the Republicans' school voucher proposal are not what the American people want. It is my hope that Republicans will not abandon our children and instead join us to pursue the goal of modern schools which have smaller classes and better discipline, and prepare our children for the jobs of the future"(p.1-2).

Leading up to the President's and Secretary Riley's May 1998 press conferences and introduction of the class size legislation are several significant reports touting small class size as an alternative to vouchers. In December 1997, Cecilia Rouse of Princeton University issued a report about the Milwaukee Choice Program, in which small class size public schools outperformed the private voucher schools in reading and math. In January 1998 Alex Molnar, professor of education at the University of Wisconsin - Milwaukee and a member of the research team at the Keystone Research Center in Harrisburg, Pennsylvania issued a report entitled "Smaller Classes, Not Vouchers, Increase Student Achievement" (p. 20). In a February 1998 article the American Federation of Teachers suggested "lower class size trumps even the most generous results from the highly contested research on vouchers" (pp. 1-4). By March 7, 1998 the press was reporting that although both sides had the same goal of higher student achievement, President Clinton's administration was pushing for reduced class size while the Republicans favored vouchers and school choice (Stanfield, 1998, p. 506). In April, 1998, the International Reading Association characterized the issue similarly by stating, "in Washington, DC Republicans are pushing a voucher program and a new block grant, while Democrats are seeking to reduce class size..."(Long, p. 24). In the next month the class size issue appeared on the President's 
agenda through a message from the President transmitted May 11, 1998 and referred to the Committee on Education and the Workforce, entitled Class-size Reduction and Teacher Quality Act of 1998. A bill, H.R. 3876, was introduced at the same time in Congress by Democratic House members lead by Rep. Clay.

The political framing of small classes versus vouchers continued until the legislation was passed in the 1998 Omnibus Spending Bill. On September 30, 1998, just two weeks before passage of the bill, the Wall Street Journal stated that, former First Lady "Hillary Clinton was pushing one of her party's big answers to the GOP's school voucher proposals. She wants to make classes smaller by hiring yet more teachers." (1998, p. A18). It went on to editorialize in favor of the Republican voucher proposal and against the Democratic class size proposal. It is clear that throughout the year leading up to passage of the legislation, small class sizes were characterized as an alternative to vouchers. Since the 1998 polls indicated more support for decreasing class size than for vouchers, the legislation was politically more feasible than it was in prior years. Characterizing the two options as competing alternatives captured and focused the national mood on supporting smaller class sizes.

To further enhance the chances of passage, two concepts were tied to the class size legislation. First, to overcome resistance to the cost of smaller classes, the proposal was tied to the tobacco settlement funds. U.S. News and World Report (Miller, 1998, p. 32) portrayed the tobacco industry as the "magic villain" with the funds to foot the bill. Second, for those who needed to conceptualize the idea and tie it to a precedent, the legislation was touted as similar to the 1994 federal crime bill legislation that called for 100,000 cops on the streets to fight crime. With crime rates declining in recent years (New York Times, 1997, p. A18), the 100,000 cops appeared as a success story. In fact though, only about 41,000 new cops were hired and deployed of the 100,000 expected to be on the streets. The congressional subcommittee charged with overseeing the hiring reported that 2,400 more were in training and 29,000 were counted under related programs that funded various law enforcement initiatives such as technology, equipment, or civilian hiring (Mahtesian, 1999, p. 11). Furthermore, no studies indicated that the two events, more cops and a decline in the crime rate, were related. The "successful" 100,000 cops' story is similar to Deborah Stone's (1997, p. 137138) causal stories in which a metaphor or an explanation is widely shared and taken for granted without data or facts to back it up. Although the class size legislation included funding for only 30,000 teachers, the original proposal was for 100,000 and the first funds were considered a down payment on the future hiring (Mahtesian, 1999, p. 11. Thus, portraying class size policy as 100,000 teachers in the classrooms was a way to ride on the success of the cops' causal story.

\section{CONCLUSION}

It appears that the class size reduction policy is an example of Kingdon's theory of three independent streams - identification of problems, generation of policy alternatives, and finally politics - coming together during a window of opportunity to arrive at change.

It appears that a number of political factors occurred just prior to 1998 to effectively propel class size to the agenda. Class size received increased public attention during 1995 through 1998. Small class size was pitted against other school reform initiatives that threatened support for public schools. In particular, the issue during 1998 became school vouchers vs. small class size. Of the two, public opinion clearly favored class size reduction, so the education advocacy groups such as NEA, AFT, and IRA, utilized the national mood to fight these threats. Class size was a ready and waiting problem with an identified policy alternative solution that could be coupled with the political threat to public schools. This opportunity was further linked to the politically charged tobacco settlement and the decreasing crime rate. Altogether, these political forces were successful in propelling class size to the agenda.

\section{REFERENCES}

American Federation of Teachers. (1998, February). What works, recent research demonstrates major benefits of small class size. Retrieved January 29, 2003 from htto://wwwaftorg/edissues/downloads/Policy3.pdf.

Bain, H.P. and Achilles, C.M. (1986). Interesting developments in class size. Phi Delta Kappan, 67, 662-665.

Bainbridge, W. \& Sundre, S. (1990, March). School choice: The education issue of the 1990s, Peter Li Education Group. The school match guide to public schools. Simon \& Schuster Consumer Group Book.

Baumgartner, F. and Jones, B. (1993). Agendas and instability in Anterican politics. The University of Chicago Press, Chicago and London.

Bracey, G. (1995, September). Research oozes into practice: The case of class size. Phi Delta Kappan, 77.

Finn, J. (1999). Project STAR fact sheet. Health and Education Research Operative Services, Inc.

Glass, $G$, and Smith, M.L. (1979). Meta-analysis of research on class size and achievement. Educational Evaluation and Policy Analysis 1(1). 
Kingdon, J. W. (1995). Agendas, Alternatives, and Public Policies. New York: HarperCollins College Publishers.

Lee, B. (1998, May 14). Congresswoman Barbara Lee joins education Secretary Riley in support for bill to reduce class size. [Press release]. Retrieved May 23, 1999 from the World Wide Web.

Long, R. (1998, April/May). Education remains a top agenda item. Reading Today, 15 (5).

Mahtesian, C. (1999, January). Hire now, pay later. Governing Magazine.

McCants, W. (1995, October 29). Portrait of the American child, 1995. New York Times, Section 6, p. 16.

Miller, M. (1998, February 16), Budget tricks, 1998 version, U.S. News \& World Report, p. 32.

Molnar, A. (1998, March). Smaller classes - not vouchers increase student achievement. School Planning and Management, $37(3)$, p. 20 .

Most Americans favor national education standards. (1989, August 25). Xinahua News Agency, p.1.

Mosteller, F. (1998, March). Where we stand, American Federation of Teachers. Retrieved May 23, 1999 from the World Wide Web.

Mr. Giuliani picks good targets. (1997, January 15), New York Times, p. A18.

Murphy, D. \& Rosenberg, B. (1998, June). Recent research shows major benefits of small class size [Electronic version]. American Federation of Teachers Educational Policy Brief. Retrieved January 29, 2003, from http://www.aft,org/edissues/ downloads/Policy3.pdf

National Center for Education Statistics. (1990, 1992, 1994, 1996, 1998). Mathematics and reading assessments. National Assessment of Educational Progress.

National Center for Education Statistics. (1993). Common core of data survey. U.S. Department of Education. Washington, DC: Government Printing Office.

National Center for Education Statistics. (1993). Digest of education statistics. U.S. Department of Education. Washington, DC: Government Printing Office.

National Center for Education Statistics. (1997). Common core data surveys. U.S. Department of Education Publication. Washington, DC: Government Printing Office.

National Center for Education Statistics. (1997). The condition of education 1997. U.S. Department of Education Publication. Washington, DC: Government Printing Office.
National Education Association. (1999, January). Class size reduction, NEA legislative topic action center. [Retrieved May 23, 1999, from the World Wide Web].

Review and outlook. (1998, September 30). Wall Street Journal, p. A18.

Riley, R. (1998, April). Getting personal. Teaching PreK - 8, 28(7).

Rouse, C. (1997, December). Schools and student achievement: more evidence from the Milwaukee parental choice program. Princeton University and NBER. Princeton, NJ.

Slavin, R. (1999). Project STAR fact sheet. Health and Education Research Operative Services, Inc.

Stanfield, R. (1998, March 7). Education wars. The National Journal, 30 (10), p.506.

Stone, D. (1997). Policy paradox, The art of political decision making. New York: W.W. Norton \& Company, Inc. 